\title{
Features of design solutions in the design of a special-purpose building of urban infrastructure
}

\author{
Larisa Filimonova, Elena Matys, and Nadezhda Skvortsova \\ Industrial University of Tyumen, 625000, Lunacharskiy Str., 2, Tyumen, Russia
}

\begin{abstract}
The article discusses approaches to the formation of the optimal combination of design solutions in the construction of a building for funeral services. The projected facility fulfills a triple purpose: social, communal and industrial. The industrial purpose is due to the peculiarities of the assembled technological equipment and its maintenance. These are the parameters of the crematorium construction project. The contradiction in the purpose of the building can be traced in the architectural solution, the decision on the choice of engineering communications and the transport and logistics infrastructure of the environment of the object. What the authors pay attention to in their publication. The classical task of substantiating a design solution is the formation of a single information space of a capital construction object, taking into account information reflecting all stages of its life cycle. The principal distinguishing feature of the research results is the prepared set of key characteristics of the formation of project documentation, taking into account the functional parameters of the specific purpose of the projected capital construction facility, the relevance of which is undeniable both from an environmental point of view and from the standpoint of socializing society and preventing religious fanaticism.
\end{abstract}

\section{Introduction}

According to the results of an investigation by a Russian blogger, "about two million people die in Russia every year, which determines a number of factors that hinder the civilized development of society and regions. For example, the ideological function in the Russian practice of the sphere of ritual services is sometimes performed by criminalized structures. According to the blogger's investigations, "the turnover of the funeral industry only officially amounts to about 60 billion rubles a year, the size of its shadow sector, according to official sources, can reach 250 billion"[1]. There fore this cache stream does not fall under the Russian taxation and budgeting system. The cemetery plays an equally important role in the ecological potential of the region, since the traditional cemetery is a potential source of negative impact on the human environment. As a result of the decomposition of biological waste, bacteria, organic compounds, nitrogen compounds, chlorides, hydrocarbons, heavy metals. Enter the soil, rocks of the aeration zone and groundwater. «Before the ceremony, the body of the deceased is treated with formalin, which slows down the decomposition process, which is a toxic substance» [2]. 


\section{Literature Review}

According to the following sources $[2,3,4,5]$ and the report of the Tyumengeomonitoring, the current state of groundwater requires the abandonment of the traditional option of waste disposal. The report [5] was prepared on the basis of long-term data obtained in the process of conducting state monitoring of groundwater at the basic state observation network of the federal level, polygons for state monitoring of groundwater, created at the expense of the regional budget, as well as objects of local monitoring of groundwater. In general, over the year, the number of sites on which local contamination of groundwater was recorded increased from 15 to 17, which allows us to conclude that their condition has worsened.

According to the provisions of the following regulatory documents [6-12] during the design and construction of the crematorium, it is necessary to solve simultaneously two main tasks:

1. Formation of an orderly system that will provide a given passage of the service personnel.

2. Creation of the necessary environment for conducting farewell ceremonies, if possible, while maintaining the spiritual, ideological, psychological and moral halo for most categories of clients.

In addition to the basic regulatory documents for the development of project documentation, the Urban Planning Code of the Russian Federation and the Decree of the Government of the Russian Federation No. 87 are presented in table 1, a set of documents required for the development of our project of the building of the crime scene is presented.

Table 1. The normative legal support of the project.

\begin{tabular}{|c|l|}
\hline The normative Legal act & \multicolumn{1}{|c|}{ Name } \\
\hline GOST R 53999-2010 & $\begin{array}{l}\text { Household services. Crematorium services. General } \\
\text { specifications 2011 }\end{array}$ \\
\hline SNiP 2.07.01-89* & $\begin{array}{l}\text { Urban planning. Planning and development of } \\
\text { urban and rural settlements 2011 }\end{array}$ \\
\hline SanPiN 2.1.2882-11 & $\begin{array}{l}\text { Hygienic requirements for the placement, } \\
\text { arrangement and maintenance of cemeteries, } \\
\text { buildings and structures for funeral purposes 2011 }\end{array}$ \\
\hline MDC 31-5.2000 & $\begin{array}{l}\text { Recommendations for the design of objects of ritual } \\
\text { significance 2000 }\end{array}$ \\
\hline SanPiN 2.2.1/2.2.1200-03 & $\begin{array}{l}\text { Sanitary protection zones and sanitary classification } \\
\text { of enterprises, structures and other objects }\end{array}$ \\
\hline
\end{tabular}

The main provisions for the placement of funeral services should be highlighted:

1. Land plots for the construction of crematoria are recommended to be located near existing utilities and roads.

2. The location of the crematoria should be in separate areas, near the motorway.

3. The site for the construction of the crematorium should not be located near objects with a high noise regime (airports), as well as near objects and areas with unpleasant odors.

4. If the crematorium is intended only for the cremation of bodies, then it is recommended to place it outside the city, on a separate site.

5. Bus stops and parking lots should be located at a distance of no more than $150 \mathrm{~m}$ from the crematorium.

6. The sanitary protection zone from the crematorium to residential buildings must be at least 1000 meters.

7. The zone of moral protection from the crematorium, columbarium buildings, cemeteries with burials after cremations, to residential buildings must be at least 100 meters. 


\section{Results of approbation}

The result of the conducted bibliographic research (search, critical and clarifying) [6-19] should be recognized as the substantiation of the author's approach to the choice of a constructive, space-planning solution when formulating a working hypothesis.

Features of cremation architecture. Cremation architecture - is the main part of the infernal architecture (in translation "inferno" - the afterlife), which has its starting point from the Egyptian pyramids. Today, in cremation architecture, the main role is played by the ethical setting on the intensity of the influence of the image as opposed to its artistic expression, which by its nature is always subject to certain trends and trends, and therefore is not acceptable in buildings for mourning purposes. The purpose of cremation architecture is to reflect the inner content associated with grief. It should not suppress the mourning processes taking place in crematoria, and at the same time, it should not impose artistic ideas and images on one architect, who has his own associations with grief and mourning. In this connection, the authors of the article made an emphasis on figurative neutrality when forming a design solution.

The subject of this study was the demographic processes taking place in the region, as well as the theoretical and regulatory framework that determine the value and purpose of the construction of a specific-purpose facility, and the process for the disposal of biological waste that meets the principles of social and environmental efficiency.

Throughout Russia and foreign countries, where the cost of land is very high, the ratio of the number of cremations to the total number of deaths reaches $91 \%$. Based on the longterm practice of the nearest crematorium, which is located in Yekaterinburg (about $330 \mathrm{~km}$ from Tyumen), it was revealed that $60 \%$ of the total number of deaths are cremated. According to the data of the same crematorium, 12,518 cremations were carried out in 2014 , of which about 3,500 services were provided to residents of Tyumen and the South of the Tyumen region, which is $21-22 \%$ of the total mortality statistics for 2014 in the South of the Tyumen region.

Of course, at the present stage of development of society and respect for the ecosystem, an important factor is the presence of a crematorium and a columbarium in the settlement, as well as the methods of burial accepted by society and, especially, religion. Despite its technological effectiveness and rationality, cremation has not yet become widespread - both in Russia and here in Tyumen.

Sanitary protection zones and sanitary classification of enterprises, buildings and structures for crematoria are at least 1000 meters. The key provision of the working hypothesis when deciding on the choice of a land plot for the construction of a building is the remoteness from the settlement. Land plots for the construction of crematoria are chosen by the introduction of engineering communications and transport infrastructure. At the same time, the sanitary protection zone from the crematorium to residential buildings should be at least 1000 meters. The composition of the premises of the building is taken in accordance with MDS 31-5.2000 "Recommendations for the design of ritual facilities". Space-planning solution. The cremation building is classified as a production facility. The building is one-story with dimensions in the axes of $48.0 \times 18.0 \mathrm{~m}$. The height of the building is $7.4 \mathrm{~m}$. The following functional groups of premises are provided for in the building: Premises for receiving the deceased (vestibule, reception and registration room, room for refrigeration chambers, loading room); rooms for cremation of the dead (cremation room, room for processing cremated remains, rooms for storing urns, room for storing and upholstery of coffins); service (storage room and washing trolleys, rest and meal room, bathroom for staff, medical office, administration). Technical premises (boiler room, switchboard, ventilation chamber, compressor room). 
The main elements of the building are the entrance, lobby and funeral hall. The funeral hall according to MDS 31-5.2000 "Recommendations for the design of ritual facilities" is accepted according to the project, with a capacity of 20-30 people. When designing this chain, the rule of "Funnels" was laid, when, in addition to perceiving information of direct influence, the participants in the ceremony perceive the information codes contained in the architectural style of the building, as well as its design (fig.1, fig.2). We propose the following architectural technique as a basis for designing a crematorium. It consists in the ability to perceive in the most detail various parts of the furnishings (interior), such as carved wooden doors, garlands of stones. The epicenter of the congestion of participants the lobby, should adapt people, reduce their prevailing emotional state, distract the participants in the direction of the philosophical-contemplative direction. The process of ritual procession to the funeral hall is the beginning of the farewell ceremony and should create the strongest effect of the impression of solemnity. The funeral hall should provide a final impression of the entire ritual building.
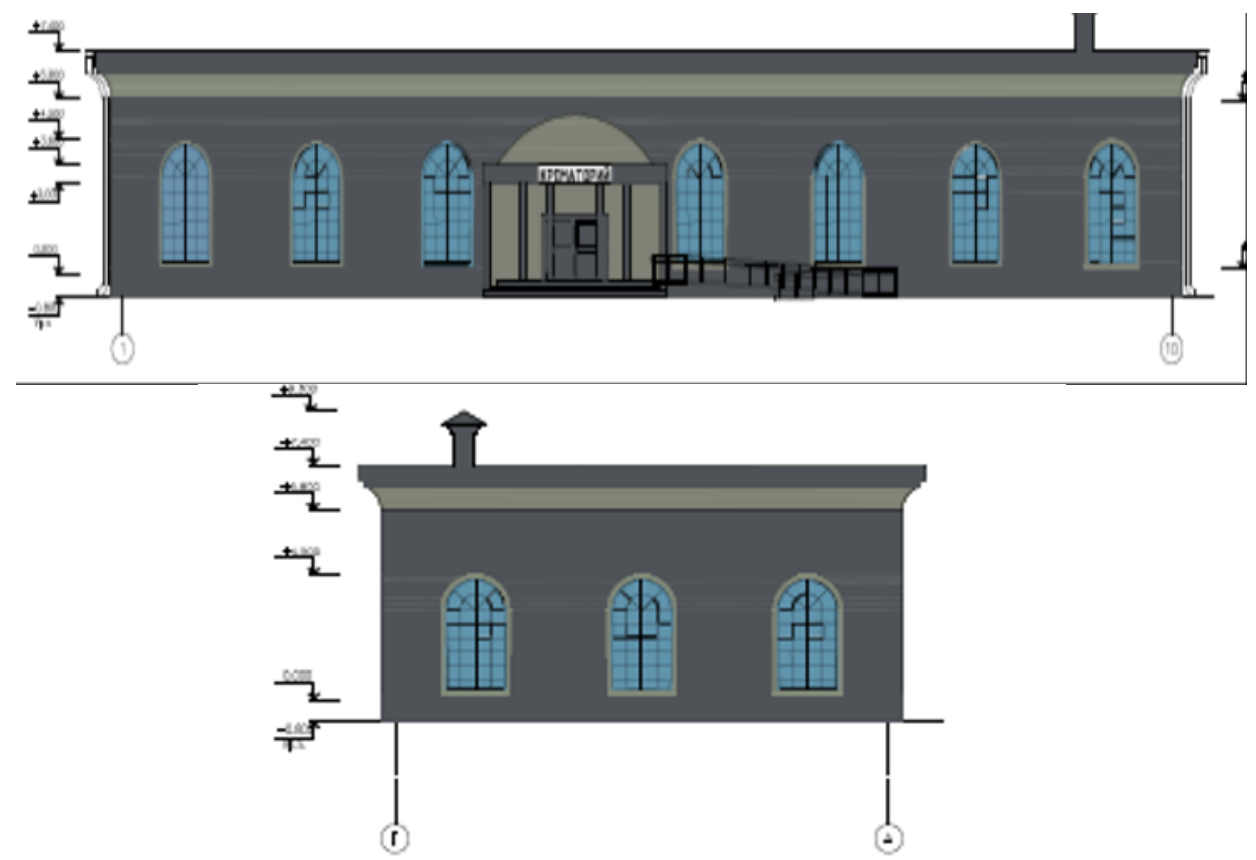

Fig. 1. Facades of the building.

Constructive solutions of the projected building: Foundations. A type: Columnar with monolithic grillages for columns. Concrete class: 20. Frost resistance grade: F100. Waterproof grade: W4. Columns. Cross section: Rectangular. Dimensions (edit) $400 * 600$. Column step: Regular according to the main center lines. Concrete class: 20. Frost resistance grade: F100. Waterproof grade: W4. Armature: A600 GOST 5781-82. Partitions. Material: Ceramic brick GOST 530-2012. Masonry mark: M50. Solution grade: M50. Thickness: 88, 120mm. Overlapping and covering. Reinforced concrete. Device method: Monolithic. Concrete class B30. Frost resistance grade: F100. Waterproof grade: W4. Armature: A600 GOST 5781-82 *, Bp-1200. Roof. A type: Flat. Sediment removal method: Internal drain. Outdoor decoration. Finishing type: Facade ceramic tiles in accordance with GOST 13996-93. Interior decoration. Finishing type: Walls and partitions are made and faced according to the "Knauf Tigi" system, followed by painting with waterbased paints. Floors. A type: Ceramic tile. 


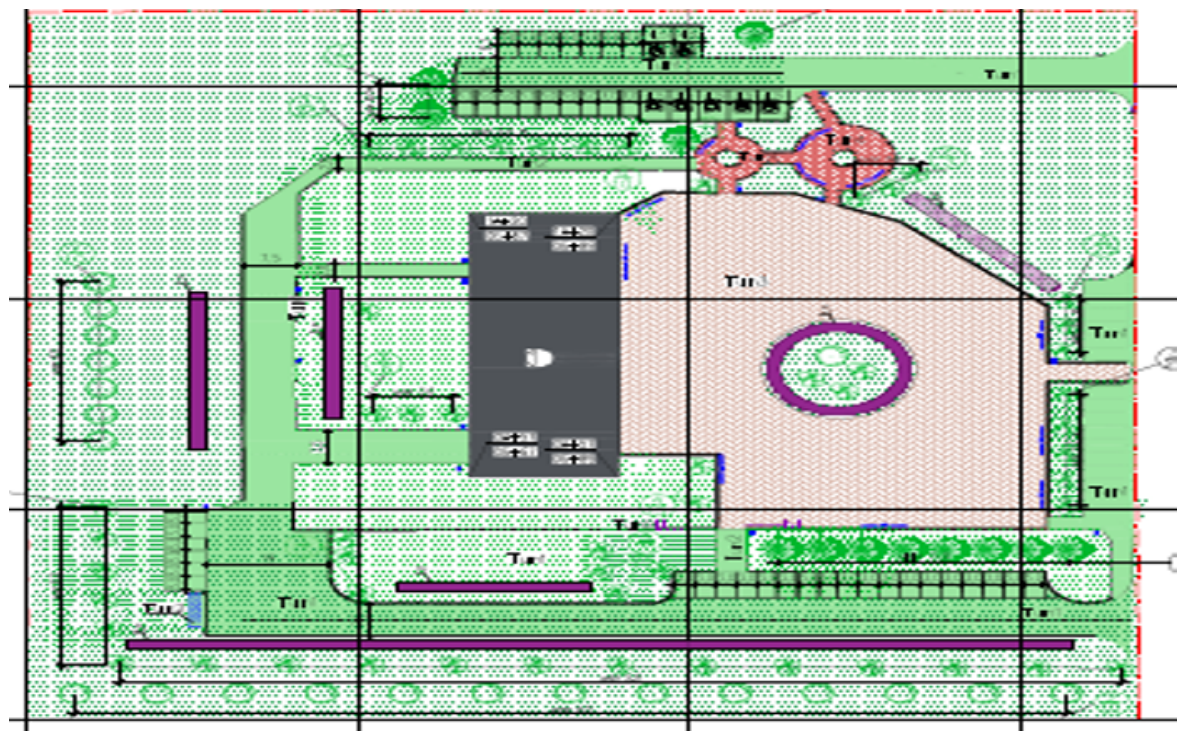

Fig. 2. General plan of the projected building.

Calculation of the throughput of the crematorium.

It is recommended to install two crematoria in single-hall crematoria, and three in twohall crematoria. The throughput of a crematorium (one crematorium, type 1) is determined on average at the rate of 1 hour 15 minutes per one cremation.In crematoria (type 2), the number of incinerators is determined by calculation. Cremation ovens must undergo an environmental and sanitary-hygienic examination, as well as have a sanitaryepidemiological conclusion. The entire crematorium building must be equipped with supply and exhaust ventilation, and the use of air conditioners (systems with air recirculation) is also not allowed.

The throughput of crematoria is set by calculation depending on the number of clients served. The capacity of the building for the funeral rites is determined by the number of possible cremations. The time of the ritual is taken from 35 to 40 minutes, the break between rituals is from 10 to 15 minutes. The time of one cremation is from 40 minutes to 1 hour, depending on the type of cremation oven. When calculating the capacity of an enterprise, the following are taken into account:

1. The mortality rate.

2. Estimated (on assignment) percentage of cremations of the total number of deaths.

3. The coefficient of unevenness of mortality (from the conditions of the season), equal to $1.33-1.5$, where the maximum falls on the spring-autumn period.

Calculation of the crematorium throughput according to MDS 31-5.2000 "Recommendations for the design of ritual facilities":

The number of funerals per year is calculated using the formula (1):

$$
N f=N p \times M r \rightarrow \max
$$

$N f$ - number of funerals per year, persons; $N p$ - number of population served, people; $\mathrm{Mr}$ - mortality rate.

The number of deaths in January - December 2019 in the Tyumen region without districts was 6,598 people $(100.7 \%$ compared to the corresponding period of 2018$)[14,15]$. The population as of 12.2019 in the Tyumen region is 1 million 537,42 thousand people 
$[14,15]$. The mortality rate for 2019 was 10.8 thousand people. The mortality rate was 0.007 . The number of funerals per year will be $1537.42 * 0.007=10.76$.

Let's determine the maximum number of cremations per day:

Of the total number of funerals per year, the percentage of cremations determined by the task should be taken into account, which will determine the maximum number of cremations per day according to the formula (2):

$$
\begin{gathered}
M A X_{c r j}^{d a y}=\frac{N f \times K_{c u}}{D w} \times K_{c r} \rightarrow \max , \\
M A X_{c r j}^{d a y}=\frac{10761 \times 2,1}{300} \times 0,3=22,6 \approx 23 \rightarrow \max ,
\end{gathered}
$$

$M A X \mathrm{cr}$ - the maximum possible number of cremations per day (capacity of the crematorium); $N f$ - is the number of funerals per year for a given city; $K \mathrm{cr}$ - cremation rate, (In Russia it is 20\%, during a pandemic from $30-40 \%$ ); $K c u$ - coefficient of unevenness (1.35-2.5); $D w$ - the number of working days of the crematorium in a year (taken equal to 300 days, taking into account weekends, holidays and sanitary days).

Calculation of the number of ovens.

The required number of ritual halls and cremation furnaces (chambers) is determined by the capacity of the crematorium, the throughput of one ritual hall and the time of one cremation in a furnace of a certain design. When determining the number of cremation ovens, it is necessary to provide for backup ovens (at least one).

The required number of furnaces is determined by the formula (3):

$$
F=\frac{T \times M A X_{c r}}{480}=\frac{40 \times 23}{480}=1.74 \approx 2,
$$

where $\mathrm{F}$ - is the required number of furnaces; $\mathrm{T}$ - Burning time with continuous cremation, $\min (1$ cremation $25-50 \mathrm{~min}$, on average $40 \mathrm{~min}$ ); $M A X \mathrm{cr}$ - the number of cremations per day.

For the crematorium, ovens will be consumed, in the amount of 2 pieces. The maximum capacity of the crematorium for continuous cremation will be 23 cremations per day.

Based on the comparison of a wide range of furnace options presented on the Russian and foreign markets, it was decided to use TABO VL-A.

Epidemiological, hygienic and infrastructural requirements for sanitary cleaning of areas adjacent to the building and the infrastructure of the project are also important in substantiating the design solution.. To implement the operational stage of the project, you need:

Modern water supply system. Whenever possible, we recommend starting an autonomous system (for example, a well) with recycling. Multi-stage purification with multiple use of industrial water for economic purposes will reduce the operating costs of the project not only for the building's water supply, but also for water disposal (sewerage). All drains from the crematorium containing toxic elements must be deeply cleaned, filtered, disinfected, disinfected to acceptable, regulated treatment and re-launched in the water supply system without being released into the general sewage system.

Internal networks of cold and hot water supply are made of PP-R PN 20 polypropylene pipes. The source of hot water supply is a universal gas boiler.External fire extinguishing is provided from 2 fire tanks with a volume of $60 \mathrm{~m} 3$ each. Water consumption for external fire extinguishing is determined according CP 8.12120.2009 (rev. No. 1) and is $10 \mathrm{l} / \mathrm{s}$. 
Modern heating system. According to the project of the building according to the project and the use of modern technological (gas) equipment for cremation, it is planned to launch an autonomous closed heating system. Allows you to approach the reduction of environmental risks, since the object is not of a level in this area of this energy during the operation of cremation furnaces.

Modern power supply system. The project should provide, in addition to traditional sources of electricity, present in the vicinity of the location of the building. Electricity is supplied through two inputs from existing external networks. The voltage at the inputs is $380 / 220 \mathrm{~V}$. Also, alternative sources, for example, when performing roofing work, provide for the installation of solar panels.

Modern ventilation system. The building is designed in accordance with the normative requirements MDS 31-5.2000 "Recommendations for the design of ritual facilities", supply and exhaust ventilation with mechanical and natural induction. A single supply ventilation system is provided for the premises: ritual halls and vestibules, cremation hall, bathrooms, refrigeration chambers. Exhaust ventilation is provided from the premises of the ritual halls with the provision of measures to prevent overturning of the draft. All air ducts to the ventilation chambers are covered with perlite plaster $20 \mathrm{~mm}$ to achieve the fire resistance limit of 0.5 hours. Exhaust ventilation is provided from the bathroom premises through ventilation ducts with natural motivation. Ventilation and ventilation are provided by means of ventilation shafts, opening windows, transoms or vents.

To exclude the penetration of unpleasant odors and noise into the ritual hall of the crematorium, it is not allowed to combine the room for the preparation of the bodies of the deceased before being placed in the coffins with the hall of farewell by the elevator shaft. To ensure safety, an automatic shading of the lift shaft opening should be provided after lowering the lift platform.

As part of the existing foreign practice, we propose to include a design solution for the implementation of BIM (Building Information Modeling) technology on the blockchain platform with adaptation to the goals and objectives of the projected building. This technology is able to provide the results of the analysis of the causes of emergencies (their manifestations) in the building not only at the request of the interested party, but also in the current mode, which allows minimizing human casualties in emergency cases. The authors of the article give recommendations on how to launch BIM in order to minimize risks and uncertainties for both the owner of the building and residents of nearby territories. The proposed technology takes into account fire-prevention measures in the project in accordance with the requirements of SNiP 2.01.01-97 "Fire safety of buildings and structures." The fire resistance of the building is II; accordingly, all structures are accepted.

The finishing materials used in the premises, as well as the space-planning and structural solutions have been selected to prevent the spread of fire.

\section{Conclusion}

The principal distinctive feature of the research results is the formulated key approaches to the formation of an optimal design solution in the development of a multipurpose building project. The authors of the article are based on the results of monitoring the existing import and "modest" domestic practice of developing and launching projects for the construction of crematoria. Thus, on the basis of the above functional capabilities of the designed building for a specific purpose, the relevance of adapting the traditional approach to design through the prism of innovative digital technologies is revealed. Digital BIM technology is able to provide up-to-date results of diagnostics of a building, technological equipment and analysis of the causes of emergency situations at the facility, not only at the request of an 
interested person, but also during operation, which allows minimizing human casualties in emergency situations.

The crematorium building, according to the authors of the article, must meet a variety of requests, which corresponds to modern trends and features of the development and purpose of the construction industry and housing and communal services:

1. Modern water supply system. Launch of an autonomous system (well) with recycling. Multi-stage purification with multiple use of industrial water for economic purposes will reduce the operating costs of the project not only for the building's water supply, but also for water disposal (sewerage). All drains from the crematorium containing toxic elements must be deeply cleaned, filtered, disinfected, disinfected to an acceptable, regulated concentration and re-launched into the water supply system without being released into the general sewage system.

2. Modern heating system. According to the purpose of the building according to the project and the use of modern technological (gas) equipment for cremation, it is advisable to launch an autonomous closed heating system. This approach helps to reduce environmental risks, since the facility will not release thermal energy into the environment during the operation of cremation furnaces.

3. Modern power supply system. The project provides, in addition to traditional sources of electricity, which are present in the vicinity of the location of the building, alternative sources. When performing roofing works, installation of solar panels is provided.

4. The ergonomics of the building is oriented towards the existing foreign practice. The project provides for the launch of BIM (Building Information Modeling) technology on the blockchain platform with adaptation to the goals and objectives of the projected building. This technology is able to provide the results of the analysis of the causes of emergency situations (their manifestations) in the building, not only at the request of the interested party, but also in the current mode, which allows minimizing human casualties in emergency cases. The authors of the article give recommendations on how to launch BIM in order to minimize risks and uncertainties for both the owner of the building and residents of nearby territories.

The proposed technology takes into account fire-prevention measures in the project in accordance with the requirements of SNiP 2.01.01-97 "Fire safety of buildings and structures." The fire resistance of the building is II; accordingly, all structures are accepted.

5. Based on the comparison of the options presented, it was decided to use the TABO VL-A furnace for the project.

This publication can serve as a basis for replicating the design solution and bringing the design documentation into the status of a reuse project.

The results of the generalization of design solutions allow us to minimize labor costs at the pre-investment stage of the implementation of a socially significant project, the relevance of which is undeniable. The authors of the article presented the rationale, conclusions and recommendations for the development and launch of a project for the construction of a building for the provision of ritual services for the cremation of organic material.

The authors of the article presented the rationale, conclusions and recommendations for the development and launch of a construction project for a building for the provision of funeral services in order to minimize risks and uncertainties for all project participants and residents of nearby territories.

\section{References}

1. I. Golunov, Coffin, cemetery, hundreds of billions of rubles (2018) https://meduza.io 
2. Administration of the Tyumen region: official site, Groundwater Contamination of the Tyumen Region: Report on the environmental situation in the Tyumen region (2020) https://admtyumen.ru

3. Scientists: Avoiding Coffins and Cremation Will Save Wildlife (2019) https://www.vesti.ru

4. Which is more environmentally friendly: cremation or burial (2019) https://www.popmech.ru

5. Administration of the Tyumen region: official site, Report of the Department of Subsoil Use and Ecology of the Tyumen Region (2020) https://pandia.ru

6. Ministry of Construction, Housing and Utilities of the Russian Federation, http://www.minstroyrf.ru

7. SanPiN 2.1.1279-03. Hygienic requirements for the placement, arrangement and maintenance of cemeteries, buildings and structures for funeral purposes, https://files.stroyinf.ru

8. MDS 31-5.2000 Recommendations for the design of objects of ritual significance, https://files.stroyinf.ru

9. SanPiN 2.2.1 / 2.2.1200-03 Sanitary protection zones and sanitary classification of enterprises, structures and other facilities, https://files.stroyinf.ru

10. SNiP 23-03-2003: SP 51.13330.2010 Protection against noise, 69 (2011)

11. CP 60.13330.2010 Heating, ventilation and air conditioning, 57 (2012)

12. SanPiN 2.1.1279-03 Hygienic requirements for the location, arrangement and maintenance of cemeteries, buildings and structures for funeral purposes (2020) https://files.stroyinf.ru

13. N. A. Surnacheva, Features of cremation architecture (2019) https://moluch.ru

14. Analytical report of the Federal Antimonopoly Service on the analysis of the funeral services market (in the context of municipal districts and urban districts (2020) http://www.ritual-grk.ru

15. Report on the analysis of the funeral services market, https://www.mos-ritual.ru

16. Ritual portal: official site, https://ritual-rus.ru

17. Cemetery "Memorial", Tyumen: official site, https://ritual-rus.ru

18. Buka cemetery. Tyumen: official site, http://izgotovleniepamyatnikov.ru

19. E. A. Yumaev, Journal of Economic Theory, 2, 181 (2017)

20. S. Logunov, Draft strategy for the development of the construction industry (2019) https://zen.yandex.ru 